\title{
Synthesis of silver nanoparticles using extract of Ocimum kilimandscharicum and its antimicrobial activity against plant pathogens
}

\author{
Rita Singh $^{1}$ (D) A. K. Gupta ${ }^{1}$ - V. Y. Patade ${ }^{1} \cdot$ G. Balakrishna ${ }^{1} \cdot$ H. K. Pandey ${ }^{1} \cdot$ Antaryami Singh $^{1}$
}

Received: 7 September 2019 / Accepted: 15 November 2019 / Published online: 21 November 2019

(c) Springer Nature Switzerland AG 2019

\begin{abstract}
Biological synthesis of silver nanoparticles using plants is gaining importance as an economically viable and ecofriendly approach. The present study reports synthesis of silver nanoparticles using an important Himalayan medicinal herbal plant Ocimum kilimandscharicum and the potential of biosynthesized silver nanoparticles for control of plant pathogens. The reducing effect of the aqueous plant extract for synthesis of silver nanoparticles was investigated at different concentrations and temperatures. UV-visible absorption spectrum recorded for samples prepared with different concentrations $(20,30,40$ and $50 \% \mathrm{v} / \mathrm{v})$ of plant extract and treated at different temperatures $\left(40,60,80^{\circ} \mathrm{C}\right.$ and room temperature) confirmed the formation of silver nanoparticles. Antimicrobial activity of the silver nanoparticles was tested against Fusarium oxysporum, Colletotrichum gloeosporioides, Bacillus sp. and Enterobacter cloacae. Complete inhibition of F. oxysporum was observed at $75 \mathrm{ppm}$ concentration of silver nanoparticles as compared to $67.75 \pm 1.15 \mathrm{~mm}$ radial growth without silver nanoparticles after 7 days of incubation. No growth of $C$. gloeosporioides was observed in vitro at 100 ppm silver nanoparticles as compared to $44.50 \pm 1.14 \mathrm{~mm}$ radial growth in the absence of the silver nanoparticles. Inhibitory effect of biosynthesized silver nanoparticles was also observed against bacterial pathogens. The highest inhibition zone of $14.5 \pm 1.11 \mathrm{~mm}$ was observed against $E$. cloacae with $100 \mathrm{ppm}$ silver nanoparticles. The obtained results confirm strong antimicrobial activity of the silver nanoparticles synthesized using $O$. kilimandscharicum against plant pathogens.
\end{abstract}

Keywords Silver nanoparticles · Ocimum kilimandscharicum · Antifungal activity · Antibacterial activity · Plant pathogens

\section{Introduction}

Management of plant pests and pathogens for controlling plant diseases and thereby reducing production losses has great economic significance and role in food security [1]. A number of bacterial and fungal pathogens are known to affect vegetable and other food crops. Various natural and artificial methods for control of plant diseases have been applied. Synthetic chemical fungicides and pesticides are most commonly used in agriculture for control of plant diseases. Extensive use of fungicides and pesticides is causing environmental pollution and poses a potential risk to human health [2]. The chemicals used for control of disease are also affecting beneficial non-target species in the environment and impacting biodiversity.

Development of resistance in plant pathogens to commercially available fungicides due to their continuous application is also a increasing concern in recent years [3]. Emerging virulent forms of phytopathogens are also making the pathogen-resistant cultivars ineffective. Biocontrol agents as easy-to-apply and environment-friendly tool for management of plant diseases have been studied.

Rita Singh, singhritadr@yahoo.com | ${ }^{1}$ Defence Institute of Bio-Energy Research Field Station, Defence Research and Development Organisation, Pithoragarh, Uttarakhand, India. 
The antagonistic potential of several microbes has been reported [4]. However, certain difficulties are associated with biocontrol methods like host specificity and efficacy on environmental parameters. This has resulted in search for new fungicides and alternatives to combat emerging and resistant strains of plant pathogens.

Nanotechnology has immense potential in agriculture for crop protection, controlled release of agrochemicals, transfer of target genes, plant hormone delivery and early detection of plant disease using nanosensors [5]. The use of nanoparticles as safe and effective management method for control of phytopathogens is being explored [6]. Most common nanoparticles that have entered into the arena of plant disease management are nanoforms of silver [7], copper [8], chitosan [9], titanium dioxide [10], magnesium and zinc [11]. Among the metal nanoparticles, efforts have been focused on using silver nanoparticles in agriculture for control of plant pathogens.

Silver nanoparticles are well known to exhibit strong antimicrobial activity against bacteria [12], viruses [13] and fungi [14] due to their unique physical, biological and chemical properties. Antimicrobial property of silver nanoparticles has been exploited to a great extent against a broad range of human pathogens [15]. Many workers have advocated the antibacterial and antifungal efficacy of silver nanoparticles against a diverse and broad range of plant pathogens [16]. However, the beneficial use of silver nanoparticles in agriculture to control and combat plant pathogens is not fully explored.

Chemical and physical methods for synthesis of metallic nanoparticles are often costly and associated with the use of hazardous chemicals. Several biological approaches have been developed as an alternative to obtain non-toxic, inexpensive and ecofriendly nanoparticles [17]. Biogenic synthesis of silver nanoparticles using fungi [18], bacteria [19] and plants [20] are reported. Biological synthesis method using plant is expected to have many advantages over the use of bacteria and fungi. Among these advantages are the easy availability of plants and the presence of a broad range of metabolites that aid in the synthesis of silver nanoparticles.

Ocimum kilimandscharicum Guerke belonging to the family Lamiaceae is an economically important perennial herb. Its occurrence in India was recorded first from the wild habitats of western Himalayan region, Uttarakhand. $O$. kilimandscharicum Guerke, commonly known as camphor basil (Kapur Tulsi), is highly valued for its therapeutic and aromatic properties. In traditional medicine, the plant is used for the treatment of cold, cough, malaria, abdominal pains and diarrhoea [21]. Biologically active constituents from the extracts of whole plant have insecticidal [22], fungistatic and antimicrobial activity [23]. Farmers commonly mix stored grains, pulses and other foodstuff with dry leaves or leaf powder for protection against pests. The presence of ursolic acid imparts leaves of O. kilimandscharicum therapeutic potential as an anticancer agent. $O$. kilimandscharicum Guerke is also reported to have analgesic, antiseptic and antioxidant properties.

The use of $O$. kilimandscharicum in pharmaceutical, agriculture, industrial and ornamental sectors has been explored. However, there is no report on the synthesis of silver nanoparticles using $O$. kilimandscharicum Guerke. The present study was designed with an objective of biosynthesis of silver nanoparticles using the medicinal herb O. kilimandscharicum and its potential for control of plant pathogenic fungi and bacteria.

\section{Materials and methods}

\subsection{Preparation of plant extract}

Fresh leaves from $O$. kilimandscharicum were collected from the herbal garden of Defence Institute of Bio-Energy Research Field Station located in Pithoragarh, Uttarakhand, India (Fig. 1a). Fresh leaves were surface cleaned under running tap water, followed by deionized water. Leaves $(25 \mathrm{~g})$ that had been rinsed with deionized water were finely cut into small pieces and transferred to 500 $\mathrm{mL}$ beaker. The chopped leaves were boiled in $250 \mathrm{~mL}$ of deionized water for $20 \mathrm{~min}$ and allowed to cool. The cooled leaf broth was filtered using Whatman No. 1 filter paper. The resulting extract was stored in a refrigerator at $4{ }^{\circ} \mathrm{C}$ for further use.

\subsection{Biosynthesis of silver nanoparticles}

Aqueous solution $(10 \mathrm{mM})$ of silver nitrate $\left(\mathrm{AgNO}_{3}\right)$ was prepared and transferred to an amber-coloured bottle. The aqueous leaf extract of $O$. kilimandscharicum was added
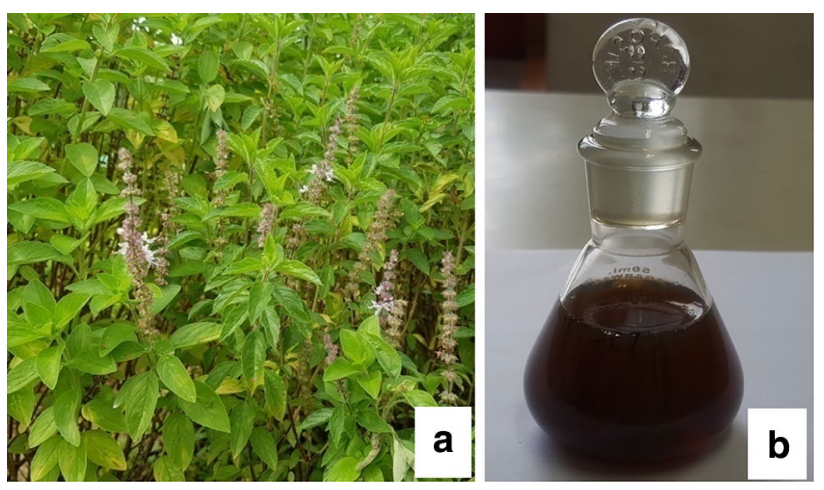

Fig. 1 a Plant of Ocimum kilimandscharicum, b silver nanoparticles synthesized using the leaf extract 
to different flasks containing $1 \mathrm{mM} \mathrm{AgNO}$ for bioreduction. Plant extract at concentrations of $20,30,40$ and $50 \%$ $(\mathrm{v} / \mathrm{v})$ was added to $1 \mathrm{mM} \mathrm{AgNO}_{3}$, and the final volume was adjusted to $100 \mathrm{~mL}$ by adding the appropriate amount of deionized water. The stoppered flasks were incubated at room temperature for $24 \mathrm{~h}$. The change in colour of the solution from yellowish to dark reddish brown was observed (Fig. 1b). The formation of silver nanoparticles in the presence of extract of $O$. kilimandscharicum was also examined under different temperature conditions. Plant extract $\left(30 \% \mathrm{v} / \mathrm{v}\right.$ ) and aqueous solution of $\mathrm{AgNO}_{3}(1 \mathrm{mM})$ were mixed. The contents were heated at different temperatures of 40,60 and $80^{\circ} \mathrm{C}$ for $20 \mathrm{~min}$. The obtained silver nanoparticle suspensions were analysed spectrophotometrically. The suspensions were subsequently examined for their antimicrobial activity.

\subsection{Determination of antioxidant constituents of the plant extract}

\subsubsection{Total phenolic content}

The total phenolic content in the plant extract was determined by using Folin-Ciocalteu method [24]. In brief, plant extract was mixed with Folin-Ciocalteu reagent and sodium carbonate (20\%). The test solutions were warmed for $1 \mathrm{~min}$, cooled, and absorbance was measured at $650 \mathrm{~nm}$. The total phenol content $(\mathrm{mg} / \mathrm{g})$ was measured equivalent to catechol by using the standard curve.

\subsubsection{Flavonoid content}

The total flavonoid content was determined by aluminium chloride colorimetric method [25]. The plant extract was mixed well with methanol, aluminium chloride solution and potassium acetate solution. Absorbance was measured after incubation for $30 \mathrm{~min}$ at $415 \mathrm{~nm}$ against the suitable blank (all reagents except aluminium chloride). The concentration of total flavonoid content $(\mathrm{mg} / \mathrm{g})$ of the sample was measured by using standard curve of quercetin.

\subsubsection{Tannin content}

Total tannin content was determined by Folin-Denis method [26]. In brief, the plant sample was boiled for 30 min with double-distilled water. The supernatant after centrifugation was mixed with Folin-Denis reagent and sodium carbonate solution. The absorbance was measured at $700 \mathrm{~nm}$ after $30 \mathrm{~min}$. Total tannin content $(\mathrm{mg} / \mathrm{g})$ of the sample was measured equivalent to tannic acid by using the standard curve.

\subsection{Determination of antioxidant activity of plant extract}

\subsubsection{DPPH free radical scavenging assay}

The total antioxidant activity was determined following the earlier reported method [27] based on free radical scavenging of DPPH (1,1-diphenyl-2-picrylhydrazyl) radicals. In brief, methanolic solution of DPPH $(0.1 \mathrm{mM})$ was mixed with various volumes of plant extract and absorbance was measured after $40 \mathrm{~min}$ at $517 \mathrm{~nm}$ against methanol as blank. Ascorbic acid was used as standard. Free radical scavenging activity (FRSA) \% of test samples was evaluated by comparing with control (DPPH with methanol).

The percentage FRSA of DPPH radicals at different concentrations was determined using the formula:

$\operatorname{FRSA}(\%)=[(\mathrm{Ac}-\mathrm{At}) / \mathrm{Ac}] \times 100$, where,

$A c=$ absorbance of control,

At $=$ absorbance of test.

Further IC-50 value $(\mathrm{mg} / \mathrm{g})$ was calculated using the formula:

$\mathrm{IC}-50$ value $=($ conc. of test $/$ FRSA nearest to the $50 \%) \times 50$

\subsubsection{ABTS free radical scavenging assay}

The total antioxidant activity in terms of ABTS $\left(2,2^{\prime}\right.$-azinobis-(3-ethylbenzothiazoline-6-sulphonic acid)) free radical scavenging was determined following an earlier reported method [28]. The percentage free radical scavenging activity of $\mathrm{ABTS}^{+}$radicals at different concentrations and IC-50 values $(\mathrm{mg} / \mathrm{g})$ was calculated as described in DPPH free radical scavenging assay.

\subsection{UV-Visible spectroscopy analysis}

The synthesized silver nanoparticles were characterized by ultraviolet-visible spectroscopy. Double-beam UV-Vis spectrophotometer UV5704SS (ECIL, Hyderabad, India) was employed for the spectrometric analysis of the biosynthesized silver nanoparticles. The bioreduction of silver and the formation of silver nanoparticles by leaf extract of $O$. kilimandscharicum were scanned in the $200-800 \mathrm{~nm}$ wavelength range. To determine the optimum conditions for maximum production of silver nanoparticles, the absorption spectra of the samples prepared with different concentrations of plant extract and at different temperatures were taken. 


\subsection{Evaluation of antifungal activity of silver nanoparticles}

Antifungal activity of silver nanoparticles synthesized by $O$. kilimandscharicum was tested in vitro against Fusarium oxysporum and Colletotrichum gloeosporioides. The test fungal cultures F. oxysporum, C. gloeosporioides were grown on potato dextrose agar (PDA) incubated at $25^{\circ} \mathrm{C}$ for three days. In vitro assay was performed using silver nanoparticles synthesized in the presence of different concentrations of plant extract and at different temperatures. Further testing was carried out with different concentrations $(25,50,75$ and $100 \mathrm{ppm})$ of silver nanoparticles synthesized in the presence of optimum concentration of plant extract and heating temperature. Medium containing silver nanoparticles was poured into $90-\mathrm{mm}$ petri dishes. Agar plugs of uniform size $(8 \mathrm{~mm}$ diameter) containing fungi were inoculated at the centre of each petri dish supplemented with silver nanoparticles. For control treatment, culture medium without silver nanoparticles was inoculated with agar plug containing fungi. The plates were incubated at $25^{\circ} \mathrm{C}$ for 7 days. Radial growth of fungal colonies was recorded after 4 and 7 days of incubation. The per cent growth inhibition was calculated using the radial growth of mycelium according to the following formula:

Inhibition rate $(\%)=(R-r) / R \times 100$

where $R$ is radial growth of fungi in control and $r$ is the radial growth of fungi in treated plates.

\subsection{Evaluation of antibacterial activity of silver nanoparticles}

The silver nanoparticles synthesized from O. kilimandscharicum were tested for their antibacterial activity by agar well diffusion method. The antibacterial assay was carried out against both gram-negative bacteria Enterobacter cloacae and gram-positive bacteria Bacillus species. The test bacterial cultures were inoculated in nutrient broth and incubated overnight at $32^{\circ} \mathrm{C}$. Fresh bacterial suspension $10^{6} \mathrm{CFU} / \mathrm{ml}$ of each strain was swabbed uniformly on the soyabean casein digest agar (SCDA) plates. Wells of size $6 \mathrm{~mm}$ were made in the agar plates using gel puncture. Different concentrations (25, 50,75 and $100 \mathrm{ppm}$ ) of synthesized nanoparticle solution to be tested were poured into wells using micropipette. The plates were incubated at $35^{\circ} \mathrm{C}$ for $24 \mathrm{~h}$. After incubation the antibacterial activity was determined by measuring the zone of inhibition $(\mathrm{mm})$ around each well. For each experiment, four replicates were performed.

\subsection{Statistical analysis}

Experiments were conducted in a completely randomized design with four replicates for all the treatments. The obtained data were analysed by analysis of variance (ANOVA) using Crop Stat (IRRI, Philippines). The mean values were compared using the Duncan's new multiple range test at 0.05 probability level.

\section{Results}

Biosynthesis of silver nanoparticles was studied using aqueous extract of leaves of $O$. kilimandscharicum. It was observed that the colour of the aqueous silver nitrate solution changed to reddish brown upon the addition of the plant extract. This indicated the formation of silver nanoparticles. No colour change was observed for plant extract solution without silver nitrate or solution with silver nitrate alone. The optical absorbance of silver nanoparticles synthesized using $O$. kilimandscharicum aqueous extract was recorded using a UV-Vis spectrophotometer. The UV-Vis absorption spectra exhibiting an absorption band around $450 \mathrm{~nm}$ confirmed the formation of silver nanoparticles using $O$. kilimandscharicum.

Phytochemical analysis of $O$. kilimandscharicum leaf extract was carried out to determine the antioxidant constituents responsible for reduction and stabilization of silver nanoparticles (Fig. 2). O. kilimandscharicum leaves were found to be rich in phenolic content. Total phenolic content was $12.48 \pm 0.08 \mathrm{mg} / \mathrm{g}$ in aqueous extract and $10.57 \pm 0.11 \mathrm{mg} / \mathrm{g}$ in methanolic extract. Flavonoids varied from $6.41 \pm 0.04$ to $7.90 \pm 0.13 \mathrm{mg} / \mathrm{g}$. Higher tannin content of $20.59 \pm 0.38 \mathrm{mg} / \mathrm{g}$ in aqueous extract and $21.42 \pm 0.08 \mathrm{mg} / \mathrm{g}$ in alcoholic extract was observed. Antioxidant property of the leaf extract was determined by DPPH assay and ABTS assay (Fig. 3). The antioxidant activity

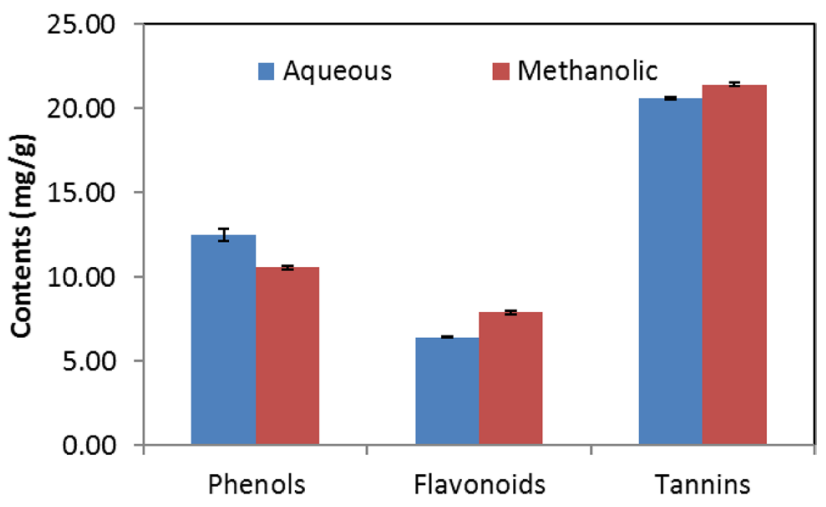

Fig. 2 Antioxidant constituents in extract of Ocimum kilimandscharicum 


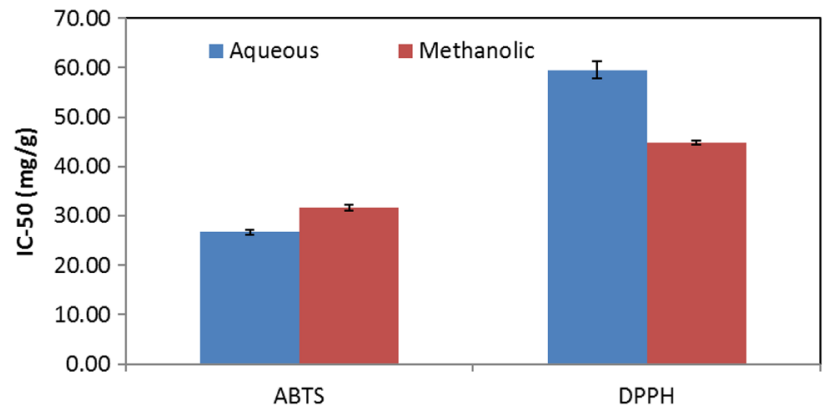

Fig. 3 Free radical inhibition concentration of aqueous and alcoholic extracts of Ocimum kilimandscharicum

of aqueous extract determined as inhibition concentration 50 (IC-50 value) was found to be $59.51 \pm 1.71 \mathrm{mg} / \mathrm{g}$ in DPPH assay and $26.66 \pm 0.51 \mathrm{mg} / \mathrm{g}$ for ABTS assay. Free radical scavenging activity was recorded to be $31.61 \pm 0.54$ to $44.83 \pm 0.37 \mathrm{mg} / \mathrm{g}$ for methanolic extract. The results confirm the presence of phenolics, flavonoids and tannins in O. kilimandscharicum that are responsible for reduction and may act as capping agent. High antioxidant constituents and strong antioxidant activity observed in the leaf extract support the synthesis of silver nanoparticles using $O$. kilimandscharicum. The effect of different concentrations of plant extract $(20-50 \% \mathrm{v} / \mathrm{v})$ on UV-Vis absorption spectra is presented in Fig. 4a. The optical properties of the silver nanoparticles synthesized using $O$. kilimandscharicum were found to be dependent on the initial concentration of the plant extract. With 20\% plant extract and $1 \mathrm{mM}$ silver nitrate solution, the absorption peak in the UV-Vis spectrum was exhibited by silver nanoparticles at $450 \mathrm{~nm}$ due to the surface plasmon resonance. Shift in wavelength of the plasmon bands was observed with different concentrations of the plant extract to the metal ion. An increase in absorbance with remarkable blue shifts in the plasmon bands was observed with $30 \%$ plant extract. With further increase in concentration of the plant extract to $40 \%$ and $50 \%$, shift in the plasmon absorption band to higher wavelength was recorded.

Temperature is an important physical parameter in the synthesis of silver nanoparticles. The synthesis of nanoparticles mediated by $O$. kilimandscharicum leaf extract was studied at $40,60,80^{\circ} \mathrm{C}$ and room temperature (Fig. $4 \mathrm{~b}$ ). An increase in absorbance with temperature for nanoparticles synthesized at 40 and $60^{\circ} \mathrm{C}$ was observed. The comparison of UV spectra at different temperatures suggests the low rate of silver nanoparticles at room temperature was enhanced by increasing the temperature of the reaction mixture. An increase in the temperature caused rapid reduction rate of the $\mathrm{Ag}+$ ions and subsequent homogeneous nucleation of silver nuclei, resulting in the formation of silver nanoparticles. Appearance of small broad surface
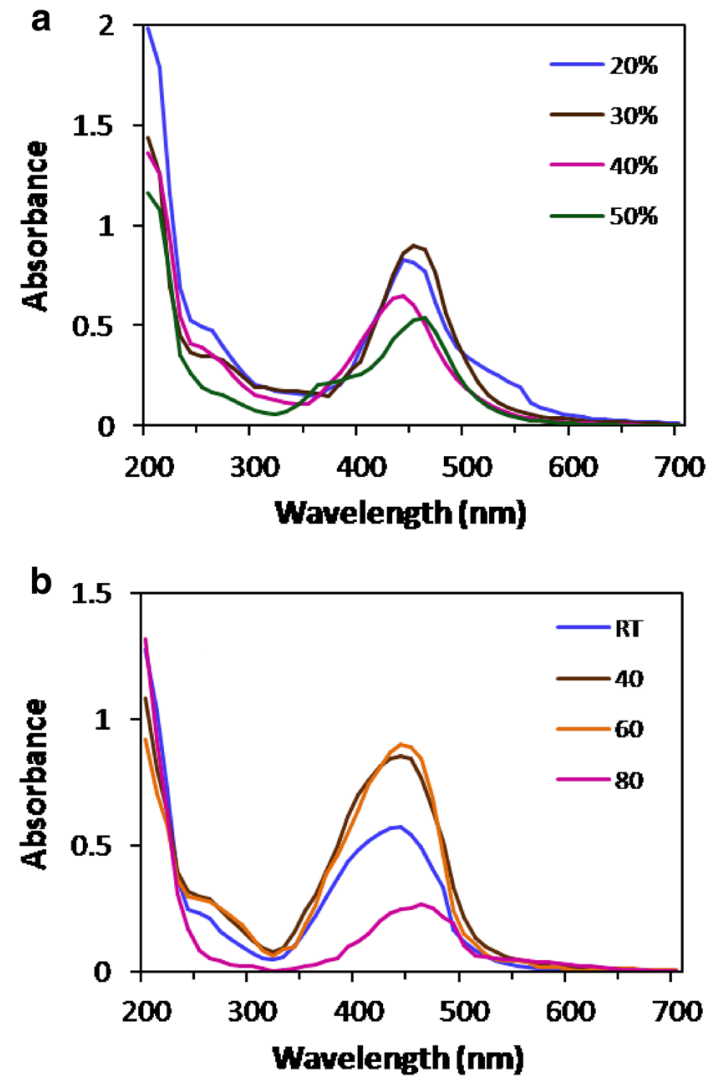

Fig. 4 UV-Vis absorption spectra of silver nanoparticles synthesized $\mathbf{a}$ in the presence of different concentrations of plant extracts and $\mathbf{b}$ at different temperatures

plasmon resonance band at higher temperature of $80^{\circ} \mathrm{C}$ indicates the formation of nanoparticles with large size.

Silver nanoparticles synthesized using different concentrations of plant extract of $O$. kilimandscharicum and at different temperatures were tested for their antimicrobial activity against plant pathogens. Antifungal activity of silver nanoparticles against $F$. oxysporum (FO) and $C$. gloeosporioides (CG) synthesized in the presence of 20 , 30,40 and $50 \%$ plant extract is presented in Fig. 5 a. Mycelial growth of fungi, as measured on the petri dishes, was used to quantify the effect of silver nanoparticles on the phytopathogens. The results show that the inhibition rate differs for silver nanoparticles synthesized with various concentrations of plant extract of $O$. kilimandscharicum. The highest inhibition of $66.5 \%$ was observed against $F$. oxysporum at $30 \%$ concentration of plant extract, and the lowest inhibition of $28.3 \%$ was observed at the highest concentration of $50 \%$ plant extract. Inhibition of C. gloeosporioides in the presence of silver nanoparticles synthesized using different concentrations of plant extract varied from 18.4 to $48.7 \%$. The result shows that the inhibition rate varies with the concentration of plant extract. Plant extract at $30 \%$ concentration was the most favourable for 

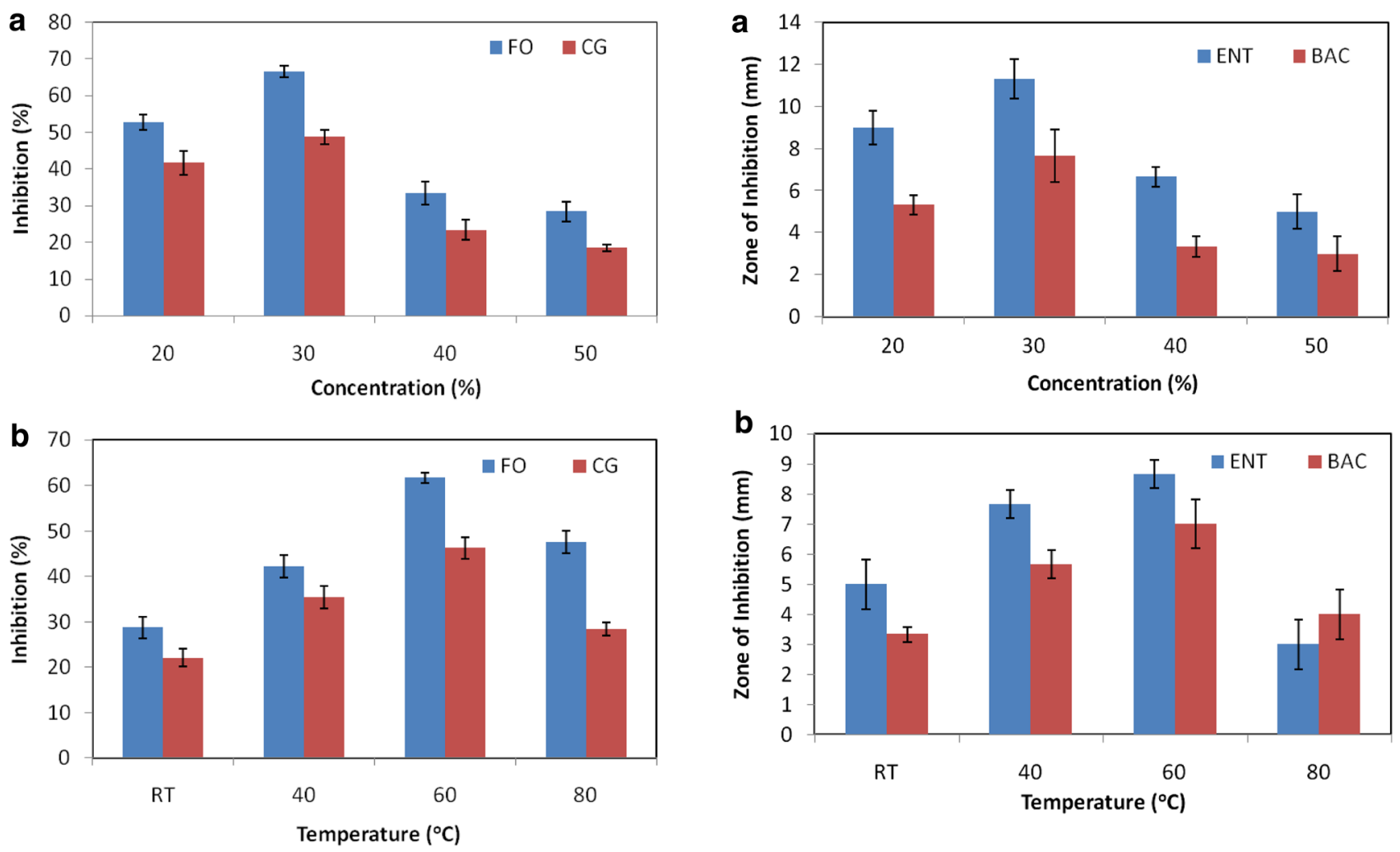

Fig. 5 Antifungal activity of silver nanoparticles synthesized $\mathbf{a}$ in the presence of different concentrations of plant extracts and $\mathbf{b}$ at different temperatures

the synthesis of silver nanoparticles and suppression of pathogens in vitro.

Antifungal activity of silver nanoparticles synthesized using extract of $O$. kilimandscharicum at different temperatures (room temperature, 40,60 and $80^{\circ} \mathrm{C}$ ) for $10 \mathrm{~min}$ is presented in Fig. $5 \mathrm{~b}$. The inhibition of $F$. oxysporum was $28.7 \%$ on PDA at $50 \mathrm{ppm}$ concentration with sample prepared at room temperature. Higher inhibition percentage was recorded with heated samples. In total, $42 \%$ inhibition for $F$. oxysporum was recorded on PDA at $40^{\circ} \mathrm{C}, 62 \%$ at $60{ }^{\circ} \mathrm{C}$ and $47 \%$ at $80^{\circ} \mathrm{C}$ temperature. The difference in growth of $C$. gloeosporioides was also observed for samples prepared at different temperatures. The inhibition rate observed with sample prepared without heating at room temperature at $50 \mathrm{ppm}$ concentration of nanosilver on PDA media was $22 \%$. The inhibitory effect of heated samples was higher than room temperature. Higher inhibition per cent of $28 \%$ to $46 \%$ for nanosilver synthesized at 40 to $80^{\circ} \mathrm{C}$ was observed. The antagonistic effect of nanosilver against fungi was more notable for the samples prepared by heating as compared to the sample at room temperature. Nanosilver synthesized using extract of $O$. kilimandscharicum had the best inhibitory effect against both the fungi on treatment at $60^{\circ} \mathrm{C}$ for $10 \mathrm{~min}$.

Fig. 6 Antibacterial activity of silver nanoparticles synthesized $\mathbf{a}$ in the presence of different concentrations of plant extracts and $\mathbf{b}$ at different temperatures

Silver nanoparticles synthesized with various concentrations of plant extract and at different temperatures were tested at concentration of $50 \mathrm{ppm}$ against bacterial species. Significant inhibition of both gram +ve Bacillus sp. and gram -ve bacteria E. cloacae with 50 ppm silver nanoparticles on soyabean casein digest agar plates was evident. Zone of inhibition observed was $7.7 \pm 1.2 \mathrm{~mm}$ for Bacillus sp. (BAC) and $11.3 \pm 0.9 \mathrm{~mm}$ for E. cloacae (ENT) in the presence of silver nanoparticles synthesized using $30 \%$ plant extract concentration (Fig. 6a). For both the bacteria, the inhibition zone was higher with silver nanoparticles synthesized using $30 \%$ plant extract as compared to $20 \%$ plant extract. The bacterial inhibition was found to decrease with further increase in plant extract concentration. The inhibition induced by silver nanoparticles synthesized at different temperatures against bacterial growth is presented in Fig. 6b. The highest inhibition zone of $7.0 \pm 0.8 \mathrm{~mm}$ for Bacillus sp. and $8.6 \pm 0.5 \mathrm{~mm}$ for E. cloacae was observed with nanosilver samples prepared at $60^{\circ} \mathrm{C}$. The inhibitory effect of silver nanoparticles increased at temperature of $40^{\circ} \mathrm{C}$ and $60^{\circ} \mathrm{C}$ as compared to room temperature. However, the inhibition zone was significantly reduced at higher temperature of $80^{\circ} \mathrm{C}$.

The silver nanoparticles synthesized with $30 \%$ plant extract of $O$. kilimandscharicum at room temperature 
Table 1 Antifungal activity of silver nanoparticles against Fusarium oxysporum

\begin{tabular}{lll}
\hline Treatment & \multicolumn{2}{l}{ Radial growth $(\mathrm{mm})$} \\
\cline { 2 - 3 } & 4 days & 7 days \\
\hline AgNP-RT25 ppm & $23.00 \mathrm{~b}$ & $45.50 \mathrm{~b}$ \\
AgNP-RT50 ppm & $14.75 \mathrm{~d}$ & $38.25 \mathrm{c}$ \\
AgNP-RT75 ppm & $0.00 \mathrm{e}$ & $0.00 \mathrm{e}$ \\
AgNP-RT100 ppm & $0.00 \mathrm{e}$ & $0.00 \mathrm{e}$ \\
AgNP-H25 ppm & $25.00 \mathrm{~b}$ & $46.75 \mathrm{~b}$ \\
AgNP-H50 ppm & $19.50 \mathrm{c}$ & $40.25 \mathrm{c}$ \\
AgNP-H75 ppm & $12.50 \mathrm{~d}$ & $28.50 \mathrm{~d}$ \\
AgNP-H100 ppm & $0.00 \mathrm{e}$ & $0.00 \mathrm{e}$ \\
Control & $44.50 \mathrm{a}$ & $67.75 \mathrm{a}$ \\
SE $(N=4)$ & 1.14 & 1.15 \\
$5 \%$ LSD & 3.34 & 3.37 \\
\hline
\end{tabular}

Mean $(N=4)$ values in a column marked with different letters are statistically significant according to least significant difference (LSD) test at $P \leq 0.05$

AgNP-RT, silver nanoparticles synthesized at room temperature; AgNP-H, silver nanoparticles synthesized at $60^{\circ} \mathrm{C}$
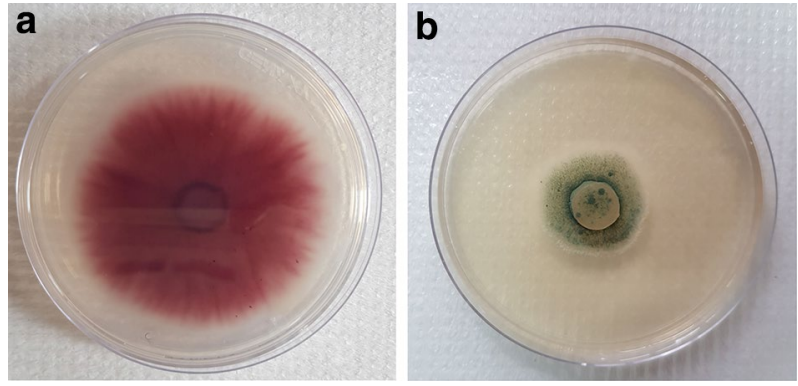

Fig. 7 Growth of a Fusarium oxysporum and b Colletotrichum gloeosporioides in the absence of silver nanoparticles

incubation for $24 \mathrm{~h}$ and heating at $60^{\circ} \mathrm{C}$ for 20 min were tested for activity against the fungal and bacterial plant pathogens. In vitro assay was carried out at different concentrations of $25,50,75$ and 100 ppm of silver nanoparticles. Antifungal activity of silver nanoparticles was studied against plant pathogenic fungus F. oxysporum. Radial growth was measured after 4 and 7 days of incubation on treatment with silver nanoparticles synthesized at room temperature incubation for $24 \mathrm{~h}$ or after heating at $60^{\circ} \mathrm{C}$ for $20 \mathrm{~min}$ (Table 1). The radial growth was significantly $(P \leq 0.05)$ higher in control $(44.50$ and $67.75 \mathrm{~mm}$ after 4 and 7 days, respectively) than the treatments with silver nanoparticles (Fig. 7a). Complete inhibition of the fungal growth was observed in silver nanoparticles (75 and 100 ppm) synthesized at room temperature (Fig. 8). In case of silver nanoparticles synthesized after heating at $60{ }^{\circ} \mathrm{C}$, the complete inhibition of the fungal growth was
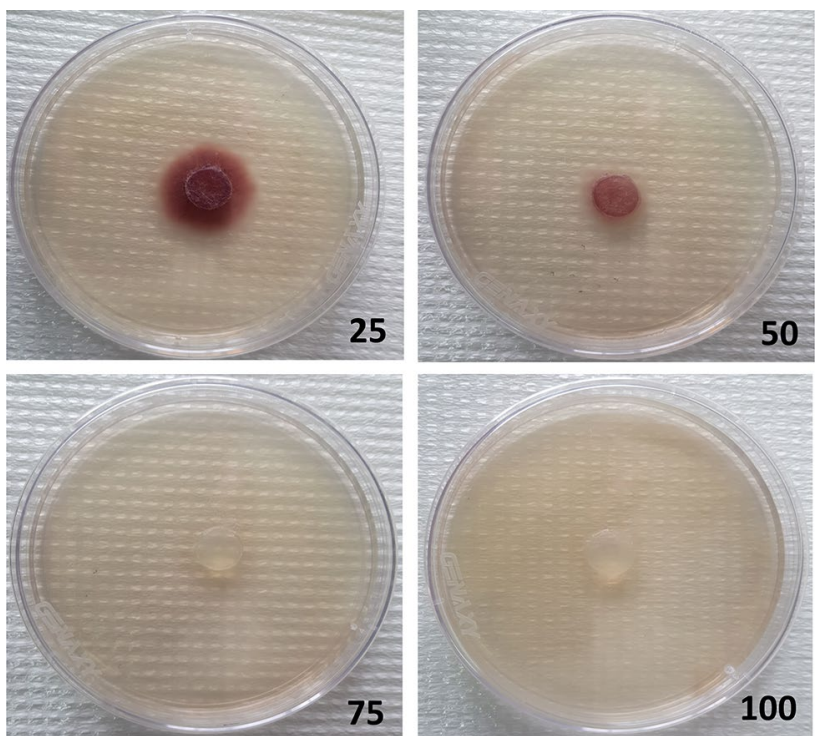

Fig. 8 Antimicrobial activity of different concentrations (25$100 \mathrm{ppm}$ ) of silver nanoparticles synthesized at room temperature against Fusarium oxysporum

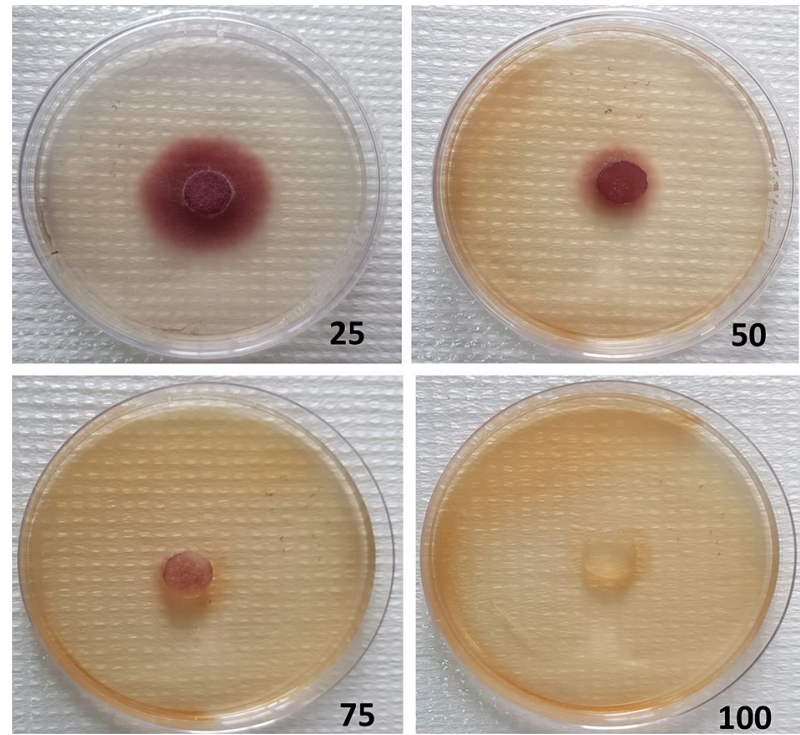

Fig. 9 Antimicrobial activity of different concentrations $(25-$ $100 \mathrm{ppm}$ ) of silver nanoparticles synthesized by heating at $60{ }^{\circ} \mathrm{C}$ against Fusarium oxysporum

observed only in 100 ppm treatment (Fig. 9). Thus, the synthesis of the silver nanoparticles at room temperature was found to be more effective than that after heating at $60^{\circ} \mathrm{C}$. The treatment with lower concentrations ( 25 or $50 \mathrm{ppm}$ ) of silver nanoparticles was not found to be effective in controlling the growth of the fungus, irrespective of the method of the synthesis.

Antifungal activity of silver nanoparticles was also studied against another plant pathogenic fungus $C$. 
gloeosporioides. The treatments with silver nanoparticles resulted in significantly lower radial growth than the control (Table 2). The radial growth was significantly $(P \leq 0.05)$ higher in control $(28.00$ and $41.00 \mathrm{~mm}$ after 4 and 7 days, respectively) than the treatments with silver nanoparticles (Fig. 7b). Complete inhibition of the fungal growth was observed in silver nanoparticles (100 ppm) synthesized at room temperature (Fig. 10). The treatments with the lower concentrations of silver nanoparticles were effective in inhibiting the growth; however, complete elimination was not observed. The complete inhibition of the fungal growth was not observed in any tested concentrations of silver nanoparticles synthesized after heating at $60^{\circ} \mathrm{C}$ (Fig. 11). Thus, synthesis of the silver nanoparticles at room temperature for $24 \mathrm{~h}$ was found to be more effective against $\mathrm{C}$. gloeosporioides than that after heating at $60^{\circ} \mathrm{C}$.

Antimicrobial activity of silver nanoparticles was studied against bacteria Enterobacter and Bacillus. Treatments with the different concentrations of silver nanoparticles significantly inhibited bacterial growth as measured in terms of zone of inhibition than the control (Table 3). Inhibition of the bacterial growth was not observed in control. Among the treatments, significantly higher zone of inhibition was observed with the higher concentrations (75 or $100 \mathrm{ppm}$ ) of silver nanoparticles synthesized at room temperature than the lower concentrations. The extent of inhibition of the bacterial growth was relatively lower on treatments with the silver nanoparticles synthesized at $60^{\circ} \mathrm{C}$ than that synthesized at room temperature.

Table 2 Antifungal activity of silver nanoparticles against Colletotrichum gloeosporioides

\begin{tabular}{lll}
\hline Treatment & \multicolumn{2}{l}{ Radial growth $(\mathrm{mm})$} \\
\cline { 2 - 3 } & 4 days & 7 days \\
\hline AgNP-RT25 ppm & $19.00 \mathrm{~b}$ & $25.75 \mathrm{~b}, \mathrm{c}$ \\
AgNP-RT50 ppm & $10.25 \mathrm{~d}$ & $21.25 \mathrm{~d}$ \\
AgNP-RT75 ppm & $4.50 \mathrm{f}$ & $14.00 \mathrm{e}$ \\
AgNP-RT100 ppm & $0.00 \mathrm{~g}$ & $0.00 \mathrm{f}$ \\
AgNP-H25 ppm & $17.25 \mathrm{~b}$ & $26.50 \mathrm{~b}$ \\
AgNP-H50 ppm & $13.75 \mathrm{c}$ & $22.75 \mathrm{c}, \mathrm{d}$ \\
AgNP-H75 ppm & $9.00 \mathrm{~d}$ & $17.00 \mathrm{e}$ \\
AgNP-H100 ppm & $6.50 \mathrm{e}$ & $15.25 \mathrm{e}$ \\
Control & $28.00 \mathrm{a}$ & $41.00 \mathrm{a}$ \\
SE $(N=4)$ & 0.68 & 1.27 \\
$5 \%$ LSD & 1.98 & 3.70 \\
\hline
\end{tabular}

Mean $(N=4)$ values in a column marked with different letters are statistically significant according to least significant difference (LSD) test at $P \leq 0.05$

AgNP-RT, silver nanoparticles synthesized at room temperature; AgNP-H, silver nanoparticles synthesized at $60^{\circ} \mathrm{C}$
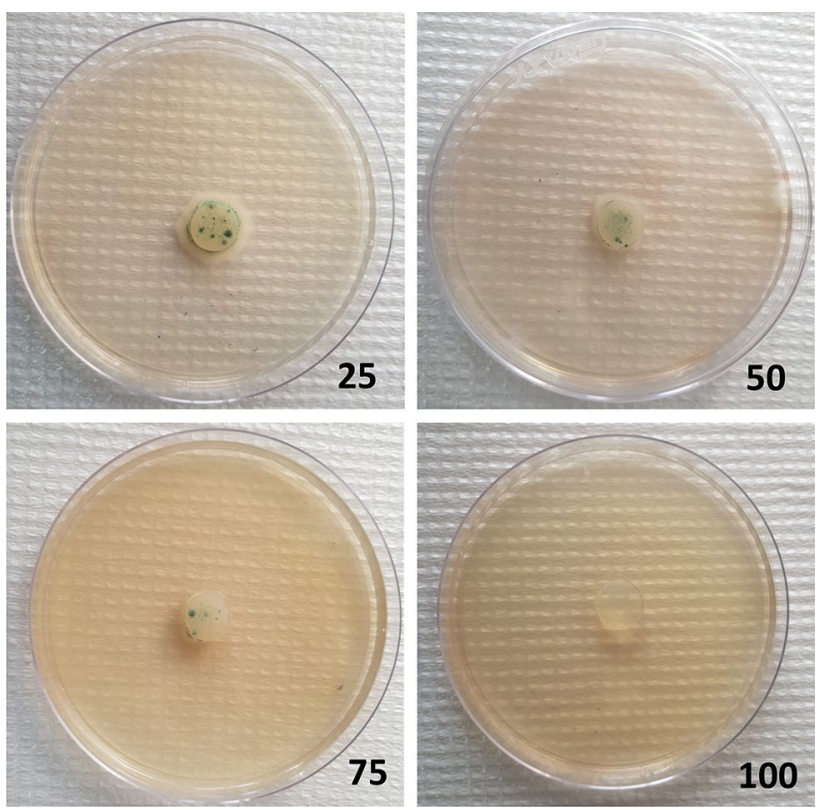

Fig. 10 Antimicrobial activity of different concentrations (25$100 \mathrm{ppm}$ ) of silver nanoparticles synthesized at room temperature against Colletotrichum gloeosporioides

\section{Discussion}

Silver and its compounds are effective and broad-spectrum antimicrobial agents [29]. Silver nanoparticles have improved antimicrobial activity due to their unique

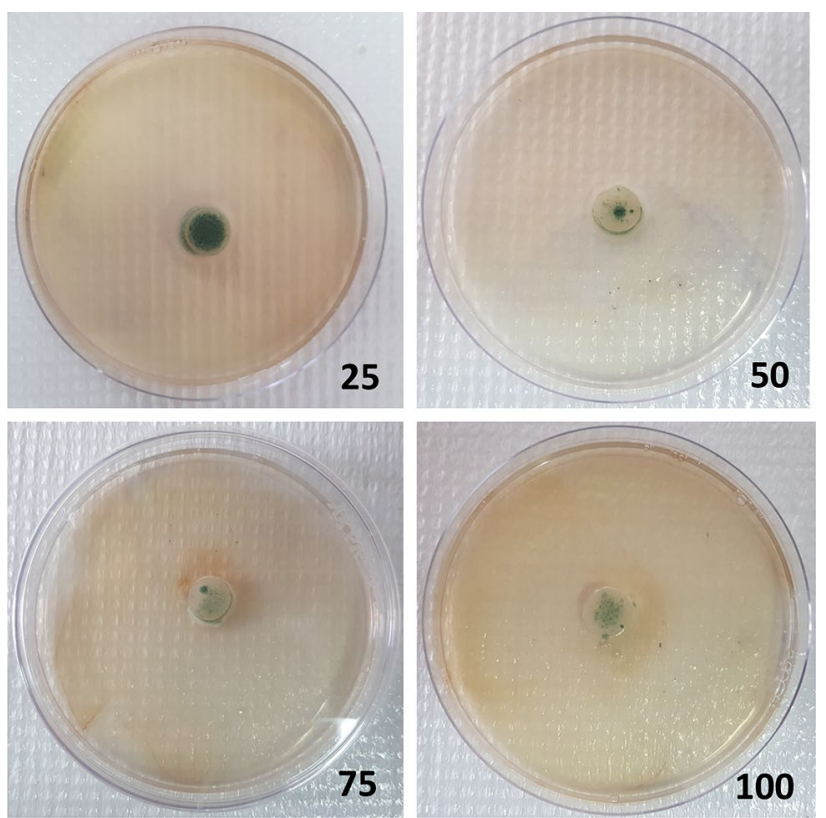

Fig. 11 Antimicrobial activity of different concentrations (25$100 \mathrm{ppm}$ ) of silver nanoparticles synthesized by heating at $60^{\circ} \mathrm{C}$ against Colletotrichum gloeosporioides 
Table 3 Antibacterial activity of silver nanoparticles against Enterobacter and Bacillus

\begin{tabular}{lll}
\hline Treatment & \multicolumn{2}{l}{ Zone of inhibition $(\mathrm{mm})$} \\
\cline { 2 - 3 } & Enterobacter & Bacillus \\
\hline AgNP-RT25 ppm & $5.5 \mathrm{~d}$ & $4.5 \mathrm{c}$ \\
AgNP-RT50 ppm & $9.5 \mathrm{~b}, \mathrm{c}$ & $5.5 \mathrm{~b}, \mathrm{c}$ \\
AgNP-RT75 ppm & $12.0 \mathrm{a}, \mathrm{b}$ & $8.0 \mathrm{a}$ \\
AgNP-RT100 ppm & $14.5 \mathrm{a}$ & $9.5 \mathrm{a}$ \\
AgNP-H25 ppm & $5.0 \mathrm{~d}$ & $3.5 \mathrm{c}$ \\
AgNP-H50 ppm & $7.0 \mathrm{c}, \mathrm{d}$ & $5.5 \mathrm{~b}, \mathrm{c}$ \\
AgNP-H75 ppm & $8.5 \mathrm{c}, \mathrm{d}$ & $7.0 \mathrm{~b}$ \\
AgNP-H100 ppm & $9.0 \mathrm{~b}, \mathrm{c}$ & $7.5 \mathrm{a}, \mathrm{b}$ \\
Control & $0.0 \mathrm{e}$ & $0.0 \mathrm{~d}$ \\
SE $(N=4)$ & 1.11 & 0.79 \\
$5 \%$ LSD & 3.25 & 2.32 \\
\hline
\end{tabular}

Mean $(N=4)$ values in a column marked with different letters are statistically significant according to least significant difference (LSD) test at $P \leq 0.05$

AgNP-RT, silver nanoparticles synthesized at room temperature; AgNP-H, silver nanoparticles synthesized at $60^{\circ} \mathrm{C}$

property of large surface area to volume ratio [30]. Reactivity of silver nanoparticles is high due to the generation of $\mathrm{Ag}^{+}$ions as compared to unreactive metallic silver [31]. Silver has multiple modes of action against broad range of microbes and thus provides benefit of avoiding development of resistance as compared to issues with chemical management of pathogens. One of the potential applications in which silver nanoparticles can be utilized is in management of plant diseases. The present study reports the successful biosynthesis of silver nanoparticles by herbal plant of western Himalayan region, O. kilimandscharicum. Several studies have been reported on plantassisted reduction of metal nanoparticles. The synthesis of silver nanoparticles using a wide range of plant extracts like Aloe vera [32], Myrmecodia pendans [33], Desmodium gangeticum [34], Indigofera barberi [35], Euphorbia helioscopia [36], Artimisia vulgaris [37], Taraxacum officinale [38], Convolvulus arvensis [39] is reported. The main phytochemicals responsible for biosynthesis of silver nanoparticles are alkaloids, terpenoids, phenolic compounds, enzymes, coenzymes, protein and sugars [17]. Phytochemical analysis of $O$. kilimandscharicum leaf extract was carried out to verify the role of various functional groups in the bioreduction of silver. The plant O. kilimandscharicum was found to be a good source of phenolic compounds, flavonoids and tannins which are responsible for the transformation of silver ions to silver nanoparticles. Biocompounds in the plant extract of $O$. kilimandscharicum reduce silver metal salt from positive oxidation state to zero oxidation state.
Biomolecules also form a monolayer on the surface of nanoparticles to prevent the agglomeration.

The silver nanoparticles synthesized using $O$. kilimandscharicum showed bright reddish brown colour reflecting the reduction of $\mathrm{Ag}^{+}$into $\mathrm{Ag}^{0}$. The characteristic reddish brown colour of colloidal silver solution is attributed to collective oscillation of free conduction electrons induced by an interacting electromagnetic field [40]. The colour density also depends on the size of the synthesized silver nanoparticles. The UV-Vis spectrum exhibited an absorption band at around $450 \mathrm{~nm}$, which is characteristic for silver nanoparticles.

The effect of the variation of plant extract concentration and temperature on the biosynthesized silver nanoparticles was investigated using UV-Vis spectroscopy. The absorption increased with the increase in the concentration of plant extract from 20 to $30 \%$. The nanoparticles synthesis and size reduction was optimum at these concentrations due to the availability of reducing functional groups in the leaf extract. Higher concentration of plant extract resulted in decrease in intensity of the plasmon band and broad peak due to larger size and aggregation of nanoparticles. An optimal concentration of plant extract is required as there could be aggregation, which leads to reduction in total number of nanoparticles in the presence of higher concentrations of plant extract. At higher concentrations of $40 \%$ and $50 \%$ plant extract, the absorption band becomes broader and shifts towards the red region. This may be attributed to the presence of large amounts of phytomolecules at higher concentration that causes the rapid reduction of silver ions. The fast reduction of silver ions results in further growth of nanoparticles that leads to an increase in the size of nanoparticles by a phenomenon called Ostwald ripening [41].

The formation of the silver nanoparticles was observed at room temperature $\left(25^{\circ} \mathrm{C}\right)$ with a characteristic plasmon band at $450 \mathrm{~nm}$. An increase in the intensity of the nanoparticles and narrowing of the peaks was observed at temperatures from 40 to $60^{\circ} \mathrm{C}$ which suggests reduction in particle size. A decrease in intensity and red shift was observed at higher temperature of $80^{\circ} \mathrm{C}$. Red shift or blue shift in the UV absorption peak characteristic of silver nanoparticles depends on the particle size, shape, aggregation and the surrounding dielectric medium [42]. A shift in the absorption maxima to longer wavelength and bandwidth increase, results with the increase in size of the nanoparticles [43]. The reduction in the concentration of nanoparticles and size increase may be due to desorption of the biomolecules at higher temperature, thereby reducing the concentration of the silver nanoparticles formed.

Fusarium oxysporum and C. gloeosporioides are the prevalent disease causing fungi affecting vegetable crops. Therefore, in this study we attempted to evaluate the 
efficacy of biosynthesized silver nanoparticles for control of phytopathogens F. oxysporum and C. gloeosporioides. The results of the present study demonstrate that silver nanoparticles synthesized using $O$. kilimandscharicum have the capacity to inhibit the growth $F$. oxysporum and C. gloeosporioides. Growth of the fungi was inhibited at different concentrations of 25 to 100 ppm silver nanoparticles. The inhibition was increased with the increase in concentration of silver nanoparticles. The inhibitory effect was observed in a concentration-dependent manner in both fungi.

The highest antifungal properties were observed on treatment with $100 \mathrm{ppm}$ silver nanoparticles in vitro. The results are in corroboration with other studies available on the effects of silver nanoparticles on phytopathogens. The antifungal effects of different concentrations of silver nanoparticles (20 to $100 \mathrm{ppm}$ ) were studied against aggressive isolates of Botrytis fabae and Alternaria alternate causing chocolate spot disease and Alternaria leaf spot disease of faba bean [44]. The highest reduction of chocolate spot and Alternaria leaf spot severity was obtained with treatment by $100 \mathrm{ppm}$ of silver nanoparticles. Abdelmalek and Salaheldin [45] studied silver nanoparticles as a potent fungicide for citrus phytopathogenic fungi. In vitro assay was carried out on potato dextrose agar (PDA) media treated with 50, 100 and 150 ppm of silver nanoparticles. Results revealed that $150 \mathrm{ppm}$ silver nanoparticle showed potent antifungal activity against the isolated fungi Alternaria alternate, Alternaria citri and Penicillium digitatum. Kim et al. [14] studied antifungal effects of silver nanoparticles against eighteen different plant pathogenic fungi on potato dextrose agar, malt extract agar and corn meal agar plates. The most significant inhibition of plant pathogenic fungi was observed on PDA with 100 ppm of silver nanoparticles. Application of silver nanoparticles for the control of Colletotrichum species in vitro and pepper anthracnose disease in field is reported by Lamsal et al. [16]. Silver nanoparticles were applied at various concentrations to determine antifungal activities in vitro and in the field. The application of 100 ppm concentration of silver nanoparticles produced maximum inhibition of the growth of fungal hyphae as well as conidial germination in comparison with the control in vitro.

The biogenically synthesized nanoparticles by leaves of O. kilimandscharicum were tested against two pathogenic bacteria, namely E. cloacae and Bacillus sp. Strong antibacterial activity was observed against the test bacteria. Antimicrobial mechanism of silver is attributed to disruption of a broad range of biological processes in micro-organisms. A number of studies have demonstrated the release of silver ions from silver nanoparticles that are responsible for the antimicrobial activity [46]. Silver ions inhibit the cell membrane structure and functions $[47,48]$ and also the expression of proteins associated with adenine triphosphate production [49]. Several studies have shown that silver nanoparticles may kill fungal spores by destructing the membrane integrity [50]. It has also been indicated that interaction of silver nanoparticles with phosphorus and sulphur-containing compounds may cause damage to DNA and proteins, resulting in cell death [51]. Reactive oxygen species are also produced by silver ions via their reaction with oxygen which causes damage to proteins, lipids and nucleic acids [52].

\section{Conclusion}

In this study, biosynthesis of silver nanoparticles using aqueous leaf extract of $O$. kilimandscharicum is reported. UV-Vis absorption spectra displayed surface plasmon resonance characteristic of silver nanoparticles. Biosynthesized silver nanoparticles exhibited potent antifungal and antibacterial activity against all the tested pathogens. Silver nanoparticles synthesized using 30\% leaf extract demonstrated the highest antimicrobial activity. It is evident from the present study that silver nanoparticles synthesized using $O$. kilimandscharicum have great potential in agriculture as an effective antimicrobial agent against the harmful plant pathogens.

Acknowledgements Authors are grateful to the Director, Defence Institute of Bio-Energy Research, Haldwani, for the support.

\section{Compliance with ethical standards}

Conflict of interest The authors declare that there is no conflict of interest.

\section{References}

1. Flood J (2010) The importance of plant health to food security. Food Secur 2:215-231

2. Bartlett DW, Clough JM, Godwin JR, Hall AA, Hamer M, ParrDobrzanski B (2002) The strobilurin fungicides. Pest Manag Sci 58:649-662

3. Goffeau A (2008) Drug resistance: the fight against fungi. Nature 452:541-542

4. Hanada RE, Pomella AWV, Soberanis W, Loguercio LL, Pereira JO (2009) Biocontrol potential of Trichoderma martiale against the black-pod disease (Phytophthorapalmivora) of cacao. Biol Control 50:143-149

5. Ghormade V, Deshpande MV, Paknikar KM (2011) Perspectives for nano-biotechnology enabled protection and nutrition of plants. Biotechnol Adv 29:792-803

6. Worrall EA, Hamid A, Mody KT, Mitter N, Pappu HR (2018) Nanotechnology for plant disease management. Agronomy 8:285

7. Jo YK, Kim BH, Jung G (2009) Antifungal activity of silver ions and nanoparticles on phytopathogenic fungi. Plant Dis 93:1037-1043 
8. Kanhed P, Birla S, Gaikwad S, Gade A, Seabra AB, Rubilar O, Duran N, Rai M (2014) In vitro antifungal efficacy of copper nanoparticles against selected crop pathogenic fungi. Mater Lett 115:13-17

9. Brunel F, El Gueddari NE, Moerschbacher BM (2013) Complexation of copper(II) with chitosan nanogels: toward control of microbial growth. Carbohydr Polym 92:1348-1356

10. Paret ML, Vallad GE, Averett DR, Jones JB, Olson SM (2013) Photocatalysis: effect of light-activated nanoscale formulations of $\mathrm{TiO}_{2}$ on Xanthomonas perforans and control of bacterial spot of tomato. Phytopathology 103:228-236

11. Wani AH, Shah MA (2012) A unique and profound effect of $M g O$ and $\mathrm{ZnO}$ nanoparticles on some plant pathogenic fungi. J Appl Pharm Sci 2:40-44

12. Singh $R$, Singh $D$ (2014) Chitin membranes containing silver nanoparticles for wound dressing application. Int Wound J 11:264-268

13. Bekele AZ, Gokulan K, Williams KM, Khare S (2016) Dose and size-dependent antiviral effects of silver nanoparticles on feline calicivirus, a human norovirus surrogate. Foodborne Pathog Dis $13: 239-244$

14. Kim SW, Jung JH, Lamsal K, Kim YS, Min JS, Lee YS (2012) Antifungal effects of silver nanoparticles (AgNPs) against various plant pathogenic fungi. Mycobiology 40:53-58

15. Singh R, Shitiz K, Singh S, Jha S, Singh A (2018) Evaluation of wound dressing properties of chitin membranes containing nanosilver. Biomed Phys Eng Express 4:025030

16. Lamsal K, Kim SW, Jung JH, Kim YS, Kim KS, Lee YS (2011) Application of silver nanoparticles for the control of Colletotrichum species in vitro and pepper anthracnose disease in field. Mycobiology 39:194-199

17. Roy A, Bulut O, Some S, Mandal AK, Yilmaz MD (2019) Green synthesis of silver nanoparticles: biomolecule-nanoparticle organizations targeting antimicrobial activity. RSC Adv 9:2673-2702

18. Zhao X, Zhou L, Rajoka MSR, Yan L, Jiang C, Shao D, Zhu J, Shi J, Huang Q, Yang H, Jin M (2018) Fungal silver nanoparticles: synthesis, application and challenges. Crit Rev Biotechnol 38:817-835

19. Gopinath V, Velusamy $P$ (2013) Extracellular biosynthesis of silver nanoparticles using Bacillus sp. GP-23 and evaluation of their antifungal activity towards Fusarium oxysporum. Spectrochim Acta A Mol Biomol Spectrosc 106:170-174

20. Bilal M, Rasheed T, Iqbal HMN, Hu H, Zhang X (2017) Silver nanoparticles: biosynthesis and antimicrobial potentialities. Int J Pharmacol 13:832-845

21. Gill D, Soni N, Sagar BPS, Raheja S, Agarwal S (2012) Ocimum kilimandscharicum: a systematic review. J Drug Deliv Ther 2:45-52

22. Singh $P$, Jayaramaiah $R H$, Sarate $P$, Thulasiram HV, Kulkarni MJ, Giri AP (2014) Insecticidal potential of defense metabolites from O. kilimandscharicum against Helicoverpa armigera. PLoS ONE 9(8):e104377

23. Sethi S, Prakash O, Chandra M, Punetha H, Pant AK (2013) Antifungal activity of essential oils of some Ocimum species collected from different locations of Uttarakhand. Ind J Nat Prod Resourc 4:392-397

24. Malik CP, Singh MB (1980) Plant enzymology and histo-enzymology. Kalyani Publishers, New Delhi

25. Chang CC, Yang MH, Wen HM, Chern JC (2002) Estimation of total flavonoid content in propolis by two complementary colorimetric methods. J Food Drug Anal 10:178-182

26. Schanderi SH (1970) Methods in food analysis. Academic Press, New York

27. Hatano T, Edamatsu R, Hiramatsu M, Mori A, Fujita Y, Yasuhara T, Yoshida T, Okuda T (1989) Effects of the interaction of tannins with co-existing substances. VI. Effects of tannins and related polyphenols on superoxide anion radical, and on 1,1-diphenyl-2-picrylhydrazyl radical. Chem Pharm Bull 37:2016-2021

28. Re R, Pellegrini N, Proteggente A, Pannala A, Yang M, RiceEvans C (1999) Antioxidant activity applying an improved ABTS radical cation decolorization assay. Free Radic Biol Med 26:1231-1237

29. Klasen $\mathrm{HJ}(2000)$ A historical review of the use of silver in the treatment of burns. II. Renewed interest for silver. Burns 26:131-138

30. Franci G, Falanga A, Galdiero S, Palomba L, Rai M, Morelli G, Galdiero M (2015) Silver nanoparticles as potential antibacterial agents. Molecules 20:8856-8874

31. Morones JR, Elechiguerra JL, Camacho A, Holt K, Kouri JB, Ramirez JT, Yacaman MJ (2005) The bactericidal effect of silver nanoparticles. Nanotechnology 16:2346-2353

32. Medda S, Hajra A, Deb U, Bose P, Mondal NK (2015) Biosynthesis of silver nanoparticles from Aloe vera leaf extract and antifungal activity against Rhizopus sp. and Aspergillus sp. Appl Nanosci 5:875-880

33. Zuas O, Hamim N, Sampora Y (2014) Bio-synthesis of silver nanoparticles using water extract of Myrmecodia pendans (Sarang Semut plant). Mater Lett 123:156-159

34. Thirunavoukkarasu M, Balaji U, Behera S, Panda PK, Mishra BK (2013) Biosynthesis of silver nanoparticle from leaf extract of Desmodium gangeticum (L.) DC. and its biomedical potential. Spectrochim Acta A Mol Biomol Spectrosc 116:424-427

35. Reddy GS, Saritha KV, Reddy YM, Reddy NV (2019) Eco-friendly synthesis and evaluation of biological activity of silver nanoparticles from leaf extract of Indigofera barberi Gamble: an endemic plant of Seshachalam Biosphere Reserve. SN Appl Sci 1:968

36. Bilal M, Rasheed T, lqbal HMN, Li C, Hu H, Zhang X (2017) Development of silver nanoparticles loaded chitosan-alginate constructs with biomedical potentialities. Int J Biol Macromol 105:393-400

37. Rasheed T, Bilal M, lqbal HMN, Li C (2017) Green biosynthesis of silver nanoparticles using leaves extract of Artemisia vulgaris and their potential biomedical applications. Colloids Surf B Biointerfaces 158:408-415

38. Rasheed T, Bilal M, Li C, lqbal HMN (2017) Biomedical potentialities of Taraxacum officinale-based nanoparticles biosynthesized using methanolic leaf extract. Curr Pharm Biotechnol 18:1116. https://doi.org/10.2174/1389201019666180214145421

39. Rasheed R, Bilal M, Li C, Nabeel F, Khalid M, Iqbal HMN (2018) Catalytic potential of bio-synthesized silver nanoparticles using Convolvulus arvensis extract for the degradation of environmental pollutants. J Photochem Photobiol, B 181:44-52

40. Dare EO, Makinde OW, Ogundele KT, Osinkolu GA, Fasasi YA, Sonde I, Bamgbose JT, Maaza M, Sithole J, Ezema F, Adewoye OO (2012) Zinc-salt-mediated synthesis, growth kinetic, and shaped evolution of silver nanoparticles. Nanomaterials 2012:376940

41. Shaik MR, Khan M, Kuniyil M, Al-Warthan A, Alkhathlan HZ, Siddiqui MRH, Shaik JP, Ahamed A, Mahmood A, Khan M, Adil SF (2018) Plant-extract-assisted green synthesis of silver nanoparticles using Origanum vulgare L. extract and their microbicidal activities. Sustainability 10:913

42. Smitha S, Nissamudeen K, Philip D, Gopchandran K (2008) Studies on surface plasmon resonance and photoluminescence of silver nanoparticles. Spectrochim Acta Part A Mol Biomol Spectrosc 71:186-190

43. Kvitek O, Siegel J, Hnatowicz V, Svorcik V (2013) Noble metal nanostructures influence of structure and environment on their optical properties. J Nanomater 2013:743684

44. Ahmed AIS (2017) Chitosan and silver nanoparticles as control agents of some faba bean spot diseases. J Plant Pathol Microbiol 8:1000421 
45. Abdelmalek GAM, Salaheldin TA (2016) Silver nanoparticles as a potent fungicide for citrus phytopathogenic fungi. J Nanomed Res 3:00065

46. Reidy B, Haase A, Luch A, Dawson KA, Lynch I (2013) Mechanisms of silver nanoparticle release, transformation and toxicity: a critical review of current knowledge and recommendations for future studies and applications. Materials 6:2295-2350

47. Pal S, Tak YK, Song JM (2007) Does the antibacterial activity of silver nanoparticles depend on the shape of the nanoparticle? A study of the Gram-negative bacterium Escherichia coli. Appl Environ Microbiol 73:1712-1720

48. Sondi I, Salopek-Sondi B (2004) Silver nanoparticles as antimicrobial agent: a case study on E. coli as a model for Gram-negative bacteria. J Colloid Interface Sci 275:177-182

49. Yamanaka M, Hara K, Kudo J (2005) Bactericidal actions of a silver ion solution on Escherichia coli, studied by energy filtering transmission electron microscopy and proteomic analysis. Appl Environ Microbiol 71:7589-7593
50. Krishnaraj C, Ramachandran R, Mohan K, Kalaichelvan PT (2012) Optimization for rapid synthesis of silver nanoparticles and its effect on phytopathogenic fungi. Spectrochim Acta A Mol Biomol Spectrosc 93:95-99

51. Feng QL, Wu J, Chen GQ, Cui FZ, Kim TN, Kim JO (2000) A mechanistic study of the antibacterial effect of silver ions on Escherichia coli and Staphylococcus aureus. J Biomed Mater Res Part B Appl Biomater 52:662-668

52. Hwang ET, Lee JH, Chae YJ, Kim YS, Kim BC, Sang BI, Gu MB (2008) Analysis of the toxic mode of action of silver nanoparticles using stress-specific bioluminescent bacteria. Small 4:746-750

Publisher's Note Springer Nature remains neutral with regard to jurisdictional claims in published maps and institutional affiliations. 